\title{
Julgamento liminar e a duração razoável do processo: ponderação entre efetividade da atividade jurisdicional e celeridade processual ${ }^{1}$
}

\author{
Alexandre de Castro Catharina ${ }^{2}$
}

\section{Resumo}

O Código de Processo Civil de 2015 aprofundou as técnicas de julgamento liminar e ampliou as hipóteses de aplicabilidade em diversas circunstâncias. Essas inovações normativas têm como principal escopo assegurar o julgamento célere das causas que não demandem maiores dilações probatórias ou mesmo as demandas seriais, observando, sempre, os precedentes judiciais das Cortes superiores. É verdade que o julgamento antecipado contribui diretamente para dar maior celeridade à atividade jurisdicional e, como consequência, assegurar a plena eficácia da administração da justiça. Entretanto, importa compreender em que medida essa celeridade contribui para efetividade da atividade judicante. A proposta deste trabalho, portanto, tem como escopo refletir sobre a necessária ponderação entre efetividade do processo, sua duração razoável e a celeridade processual no âmbito do julgamento liminar. Para tanto, utilizamos o método de pesquisa bibliográfico, com o escopo de levantar o estado da arte sobre o tema.

Palavras-chave: Julgamento liminar. Duração razoável do processo. Efetividade da tutela jurisdicional.

\section{Liminar judgment and the reasonable duration of the process: weighting between the effectiveness of jurisdictional activity and procedural celery}

\begin{abstract}
The Code of Civil Procedure of 2015 deepened the techniques of preliminary injunction in several circumstances. These normative innovations have as main scope to assure the rapid judgment of the causes that do not demand further proof delays or even the serial demands. Certainly, early judgment directly contributes to speeding up jurisdictional activity and, as a consequence, efficiency in the administration of justice. However, it is important to understand

\footnotetext{
${ }^{1} \mathrm{O}$ artigo trata dos resultados parciais da pesquisa realizada com o apoio do Programa de Pesquisa Produtividade da Universidade Estácio de Sá, 2019-2020.

${ }^{2}$ Doutor em Sociologia pelo IUPRJ/UCAM. Professor de Direito Processual Civil da Universidade Estácio de Sá. Professor do Programa de Pós-Graduação stricto sensu em Direito da Universidade Estácio de Sá Pesquisador Produtividade da Universidade Estácio de Sá, 2020-2021. Coordenador do Observatório de Cultura Jurídica Processual e Democratização do Processo, Campus Nova América, UNESA, RJ. Membro do Instituto dos Advogados do Brasil - IAB. Membro do Instituto Brasileiro de Direito Processual - IBDP. Advogado.
} 
to what extent this celerity contributes to the effectiveness of the judging activity. The purpose of this work is to reflect on the necessary balance between the effectiveness of the process, its reasonable duration and the speed of process. To do so, we used the method of bibliographic research, with the purpose of raising the state of art on the subject.

Keywords: Preliminary trial. Reasonable duration of the proceedings. Effectiveness of judicial protection.

\section{INTRODUÇÃO}

O Código de Processo Civil de 2015 ampliou as hipóteses de incidência de julgamento liminar com o objetivo de aperfeiçoar a prestação da tutela jurisdicional mediante a vinculação do juízo de primeiro grau aos precedentes judiciais dos tribunais superiores. Pretendeu-se, portanto, evitar decisões díspares sobre demandas idênticas, por um lado, e, por outro, evitar perda de tempo e energia com ações judiciais cujo desfecho é previsível em razão do entendimento pacificado dos tribunais.

Embora o julgamento liminar tenha amparo na literatura processual contemporânea, nacional e estrangeira, certo é que sua aplicação inadequada ou indevida pode comprometer o amplo acesso à justiça e o devido processo legal, princípios basilares do direito constitucional processual, que foram incorporados no novo código como normas fundamentais do processo civil (arts. $3^{\circ}$ e $7^{\circ}$ ). É neste contexto que se faz necessário maior controle na aplicação do julgamento liminar disposto no art. 332 do CPC.

Diante disto, a proposta deste trabalho é, num primeiro momento, traçar o desenvolvimento normativo do julgamento liminar na processualística brasileira e, num segundo momento, refletir sobre a contribuição do instituto para a efetividade do processo, seus principais desafios, do ponto de vista práxis judiciária, e, por fim, as formas de controle em sua aplicação no âmbito do primeiro grau de jurisdição. Essa linha de reflexão será o fio condutor da perspectiva teórica que será abordada no texto.

A implementação de um instituto do direito processual, sobretudo quando se pretende como essencial para o aprimoramento da atividade jurisdicional, não deve prescindir de uma análise crítica, do ponto de vista conceitual e normativo, e, principalmente, sobre impacto da aplicação deste instituto na cultura jurídica processual que se pretende transformar. É neste contexto que este trabalho se insere.

Para abordar, de forma satisfatória, os objetivos mencionados acima, o artigo se desdobra em três partes. Na primeira parte será traçado um breve panorâmico histórico, com intuito de reconstruir, a partir das reformas legislativas, as etapas através das quais a técnica de julgamento liminar se consolidou no ordenamento processual brasileiro. Num segundo momento do artigo, serão abordadas as hipóteses de improcedência liminar do pedido retratadas no Código de Processo Civil. 
Na terceira e última parte do trabalho se defenderá a hipótese central da pesquisa, no sentido de que a técnica de julgamento liminar deve ser manuseada informada pelas normas fundamentais do processo civil, em especial pelos princípios do contraditório, da cooperação, da duração razoável do processo e, por fim, da primazia do mérito. Pretende-se, por fim, ressaltar que a teoria da decisão judicial, que conforma o Código de Processo Civil de 2015, não pode prescindir de um contraditório eficaz e substancial.

A metodologia que consubstancia a pesquisa é o levantamento bibliográfico, com a finalidade de levantar o estado da arte sobre o tema na literatura processual brasileira, de modo a nos possibilitar compreender como esta técnica de aceleração do processo foi assimilada pela doutrina especializada. A partir do levantamento bibliográfico levado efeito, pretende-se estabelecer os conceitos que informam esta técnica de julgamento liminar com a finalidade de viabilizar, em outro trabalho, pesquisas empíricas necessárias para apreensão dos impactos da improcedência liminar impactou em nossa cultura jurídica processual.

\section{JULGAMENTO LIMINAR NO PROCESSO CIVIL BRASILEIRO}

A proposta de julgamento liminar com base em decisões paradigmáticas não é nova em nosso ordenamento processual. A crise do Judiciário, caracterizada pelo número excessivo de processos $^{3}$, ensejou diversas reformas processuais no período de vigência do Código de Processo Civil de 1973.

A Lei $n^{\circ}$ 9.756/1998 deu nova redação ao art. 557 do código revogado, atribuindo poderes ao relator, no âmbito da competência dos tribunais, para negar seguimento ao recurso manifestamente improcedente ou que contrariasse a jurisprudência dominante do respectivo tribunal. Por outro lado, o art. 557, §1 ${ }^{\circ}$, também com redação dada pela Lei ${ }^{\circ}$ 9.576/1998, autorizava o relator, em decisão monocrática, dar provimento ao recurso nos casos em que a decisão recorrida estivesse em manifesto confronto com as súmulas ou jurisprudência dominante do Supremo Tribunal Federal ou dos demais tribunais superiores.

A Emenda Constitucional $\mathrm{n}^{\circ} 45$, por sua vez, promoveu profunda reforma em nosso ordenamento jurídico, dentre as quais podemos destacar a instituição da súmula vinculante, como também a instauração do modelo de julgamento por meio de processo piloto no âmbito do Supremo Tribunal Federal (Lei $\left.{ }^{\circ} 11.418 / 2006\right)$ e do Superior Tribunal de Justiça (Lei ${ }^{\circ}$ 11.672/2008). Trata-se, aqui, da implementação, mesmo que de forma embrionária, dos provimentos judiciais vinculativos.

\footnotetext{
${ }^{3} \mathrm{O}$ alto índice de processos permanece mesmo na vigência do Código de Processo Civil de 2015. Segundo os dados do CNJ, publicados no Justiça em números 2018, a cada grupo de 100.000 habitantes 12.519 ingressaram com uma ação judicial em 2017. O número de ações judiciais é alto e exige técnicas processuais efetivas para serem julgadas de forma adequada e num tempo razoável. Dados disponíveis em: http://www.cnj.jus.br/files/conteudo/arquivo/2018/09/8d9faee7812d35a58cee3d92d2df2f25.pdf, acesso em 20 junho 2019.
} 
Em 2006, novas reformas processuais foram implantadas visando dar maior racionalidade à atividade judicial. A Lei ${ }^{\circ} 1.276 / 2006$ alterou a redação do art. 518 para incluir o parágrafo $1^{\circ}$, que autorizava ao juiz de primeira instância a inadmitir a apelação quando a decisão recorrida estiver em conformidade com as súmulas do Superior Tribunal de Justiça e do Supremo Tribunal Federal.

Por sua vez, a Lei $\mathrm{n}^{\circ}$ 11.277/2006 incluiu o art. 285-A, no código revogado, que permitia ao juiz de primeiro grau julgar liminarmente a demanda quando a matéria controvertida for unicamente de direito e no juízo já houvesse questão idêntica decidida. Nestes casos o juiz estava autorizada a proferir sentença de mérito antes mesmo da citação do réu ${ }^{4}$. A denominada sentença liminar disposta no art. 285-A do código revogado é, em verdade, o embrião do julgamento liminar disposto no art. 332 do Código de Processo Civil de 2015.

A técnica de improcedência liminar do art. 332 mantém, em certa medida, a proposta de julgamento liminar, antes da citação do réu, nos casos de manifesta improcedência, mas exclui a possiblidade de utilizar como fundamento para tanto as decisões proferidas pelo próprio juízo, como ocorria no regime anterior. Segundo José Miguel Medina (2015), para proferir sentença de improcedência liminar o juiz passa a ter como referencial a produção jurisprudencial dos tribunais e não mais aquilo que ele mesmo proferia em outros casos.

No que tange aos requisitos exigidos pelo código, a improcedência liminar será cabível nas causas que dispensem a fase instrutório e que estejam tramitando tanto no primeiro grau de jurisdição como também no âmbito da competência originária dos tribunais. Além dos requisitos genéricos, o código tipifica 05 (cinco) hipóteses de incidência da improcedência liminar que serão analisadas em suas particularidades nas próximas linhas.

\section{HIPÓTESES DE JULGAMENTO LIMINAR NO CPC/2015}

A exposição de motivos do Código de Processo Civil ${ }^{5}$ é contundente ao afirmar que se privilegiou a celeridade do processo, pois desconsiderar este princípio significa, em certo aspecto, corresponde à ausência de justiça. É neste contexto que a improcedência liminar constitui técnica de aceleração do processo fundante do ordenamento jurídico. Partindo desta enunciação, o código ampliou as hipóteses de incidência de julgamento liminar com a intenção de compatibilizá-las com os provimentos jurisdicionais vinculantes elencados no art. 927.

\footnotetext{
${ }^{4}$ Todas as reformas processuais ocorridas na vigência do código revogado tinha como fio condutor racionalizar a atividade jurisdicional mediante a redução do volume de demandas idênticas e da quantidade de recursos interpostos contra decisões proferidas em alinhamento com o entendimento dos tribunais superiores.

${ }^{5}$ A exposição de motivos do Anteprojeto do novo Código de Processo Civil, elaborada pela Comissão de Juristas, que tramitou no Senado Federal sob o n $379 / 2009$, foi incorporada ao Código de Processo Civil publicado pela Editora do Senado, disponível em https://www2.senado.leg.br/bdsf/bitstream/handle/id/517855/CPC_9ed_2016.pdf?sequence=3. Acesso em 21 junho 2019.
} 
Com efeito, art. 332 dispõe que, nos casos em que seja dispensável a fase instrutória, o juiz poderá julgar liminarmente o mérito, independente de citação do réu, nos casos em que o pedido do autor contrariar a) enunciado de súmula do Supremo Tribunal Federal ou do Superior Tribunal de Justiça; b) acórdão proferido pelo Supremo Tribunal Federal ou pelo Superior Tribunal de Justiça em julgamento de recursos repetitivos; c) entendimento firmado em incidente de resolução de demandas repetitivas ou de assunção de competência; d) enunciado de súmula de tribunal de justiça sobre direito local. Admite-se, ainda, o julgamento liminar nos casos em que o juiz verificar, desde logo, que ocorreu a prescrição e decadência (art. 332, $\left.\S 1^{\circ}\right)$.

Antes mesmo de aprofundar a análise acerca dos impactos do julgamento liminar no processo civil brasileiro se faz necessário compreender, em maiores detalhes, as hipóteses de cabimento elencadas no art. 332 do CPC.

\subsection{Julgamento liminar com fundamento em súmulas do STF e do STJ}

A primeira hipótese refere-se à possibilidade de julgamento liminar quando o pedido do autor contrariar súmulas do Supremo Tribunal Federal e do Superior Tribunal de Justiça. O julgamento liminar com fundamento nesta hipótese pode ser problemático se não for aplicado de forma criteriosa e atenta. Súmula não é precedente. É, em verdade, um verbete que retrata determinada tese jurídica, formada a partir substratos de importantes julgados, cujo principal escopo é facilitar a administração da justiça prestada pelos tribunais ${ }^{6}$. Exatamente por esta razão que não consta no verbete, de forma explícita, os fundamentos determinantes que ensejaram a sua edição.

Essa limitação argumentativa impede a compreensão exata da extensão de uma determinada súmula. Em outro prisma, não há como vislumbrar, num primeiro momento, se o pedido do autor, alicerçado em ampla análise dos fatos da causa, se adequa a um verbete de uma súmula sem a análise criteriosa dos julgados que foram essenciais para sua edição.

Por essas razões, se mostra preocupante, no mínimo, a aplicação do art. 332, I, do CPC. Não obstante, o código elevou as súmulas, em geral, à condição de provimento judicial vinculativo. Pode-se afirmar, em uma interpretação literal do referido dispositivo legal, que as súmulas do Supremo Tribunal Federal e do Superior Tribunal de Justiça possui força vinculativa em grau máximo para os órgãos de primeiro grau de jurisdição. A própria literalidade do dispositivo ao dizer que o juiz "julgará", comando impositivo, portanto, reforça esta interpretação.

A adequada aplicação desta hipótese de julgamento liminar exige uma cuidadosa distinção (distinguishing) por parte do juiz e das partes para evitar equívocos e arbitrariedades.

\footnotetext{
${ }^{6}$ Para Juraci Mourão (2014, p. 125) súmula constitui um ato administrativo do tribunal por meio da qual exprime o resumo do entendimento contido em uma jurisprudência dominante.
} 
Um exemplo pode nos ajudar a compreender melhor os riscos da aplicação inadequada do instituto. O Superior Tribunal de Justiça editou a súmula 302, cujo verbete possui a seguinte redação: É abusiva a cláusula contratual de plano de saúde que limita no tempo a internação hospitalar do segurado.

Ressalta-se que o verbete não faz distinção entre as modalidades de plano de saúde, podendo incidir tantos nos conflitos de interesses entre consumidores e os planos de saúde hospitalar, que contemplam internações, como também nos conflitos que envolvem práticas abusivas dos planos ambulatoriais, que em regra não cobrem internações além do período fixado em contrato. Há, porquanto, tutelas provisórias deferidas no Poder Judiciário, sobretudo nos plantões, tendo como fundamento o referido verbete ${ }^{7}$.

Conquanto, a Terceira Turma do próprio Superior Tribunal de Justiça, no Recurso Especial no 1764859/RS, julgado em 06/11/2018, sob a relatoria do Ministro Marco Aurélio Bellizze, decidiu que a súmula 302 aplica-se somente ao segmento hospitalar, excluindo de sua incidência o segmento ambulatorial. A decisão proferida no julgamento de um recurso excepcional reduziu o alcance de uma súmula, o que condiciona sua aplicação, em casos de julgamento liminar, a um determinado segmento hospitalar.

O exemplo acima evidencia que o julgamento liminar fundamentado em súmula dos tribunais superiores mencionados exige um cotejo analítico cuidadoso, do julgador de primeiro grau, para evitar improcedência liminar de forma inadequada ${ }^{8}$. Não há como pensar no julgamento liminar como forma de racionalização, ou mesmo de padronização, da atividade judicial. Se assim for feito, haverá avanço substancial na celeridade da prestação jurisdicional em detrimento do acesso qualificado à ordem jurídica justa.

Se faz necessário, com efeito, uma reformulação da prática jurídica desde a elaboração da petição inicial até o seu despacho de admissão, ou indeferimento, com escopo no cotejo analítico dos fatos debatidos nos autos e das súmulas que eventualmente poderão ser aplicadas nos termos do art. 332, I, do CPC.

\subsection{Julgamento liminar com fundamento em acórdãos do STF e recursos repetitivos do STJ}

\footnotetext{
${ }^{7}$ No Tribunal de Justiça do Estado do Rio de Janeiro há diversos julgados em que a aplicação da referida súmula foi utilizada para deferimento da medida. O julgamento do Agravo de Instrumento $\mathrm{n}^{\circ}$ 0010983-92.2019.8.19.0000 se constitui como um dado empírico importante, dentre outros, neste sentido.

${ }^{8}$ No mesmo sentido, José Miguel Medina (2015, p. 530) explicita sua reflexão sobre o tema afirmando que um enunciado sumular ambíguo, incapaz de revelar, com precisão, o sentido como um texto legal foi compreendido, ou a conclusão de um julgamento de caso repetitivo que não corresponda aos fundamentos adotados pelos ministros em votos concordantes, ou ainda, o resultado do julgamento de caso repetitivo baseado com exclusividade em fundamentos diferentes (ainda que conduzam a uma mesma conclusão), não têm aptidão para guiar a interpretação que os juízes farão no caso concreto. Nestes casos Medina propõe que não se aplique o julgamento liminar ou que somente o faça após a citação. A proposta do autor, portanto, se alinha, em alguma medida, com a hipótese central deste trabalho.
} 
$\mathrm{O}$ art. 332, II, do CPC admite julgamento liminar quando o pedido do autor contrariar acórdãos do Supremo Tribunal Federal ou decisão proferida em julgamento de recursos repetitivos. A hipótese é, no mínimo, intrigante.

$\mathrm{O}$ art. 927 do código, cuja pretensão é estabelecer um rol de decisões com força vinculante $^{9}$, dispõe que os juízes e tribunais deverão observar acórdãos proferidos pelo Supremo Tribunal Federal proferidos em controle concentrado de constitucionalidade. O dispositivo legal mencionado não contempla acórdãos proferidos pelo Corte no âmbito de sua competência recursal. A interpretação sistemática sugere, numa primeira leitura, que o código admite, para efeito de julgamento liminar, que todos os acórdãos proferidos pelo STF possuem força vinculante.

Entretanto, há necessidade de se buscar uma adequação hermenêutica entre as duas normas. A aplicação inadequada do julgamento liminar poderá ocasionar a violação do princípio do amplo acesso à justiça ${ }^{10}$, disposto no art. $5^{\circ}$ da Constituição Federal de 1988. Por essa razão, não é crível que o código atribuiu maior espectro ao julgamento liminar do que a própria estabilidade, integridade (DWORKIN, 2010) e uniformização da jurisprudência proposto pelo arts. 926 e 927.

Essa reflexão se faz necessária e premente, pois não são raros os casos de contradição entre os acórdãos proferidos pelos órgãos fracionários do STF e até mesmo entre decisões proferidas pelo Plenário da Corte. Há inúmeros exemplos neste sentido. Por esses motivos, o art. 332, II, deve ser interpretado em conjunto com o art. 927, I, do CPC, limitando-se a vinculação dos juízes de primeiro grau aos precedentes judiciais que foram formados sob o crivo do consistente debate público ${ }^{11}$ e da ampla participação dos segmentos da sociedade que serão afetados pela decisão (CATHARINA, 2015).

Em relação às decisões proferidas pelo Superior Tribunal de Justiça o código limitou o julgamento liminar aos acórdãos resultantes dos julgamentos de recursos repetitivos. Ocorre, aqui, uma importante distinção. Somente se admite, para efeitos de julgamento liminar, as decisões paradigmas do STJ em recursos repetitivos, não se admitindo a sentença de mérito sumária com fundamento em acórdãos proferidas na competência recursal comum.

As decisões paradigmáticas proferidas em julgamento de recursos repetitivos pressupõe, pelo menos em tese, intensa democratização do processo na formação da decisão judicial, sobretudo com a atuação dos amici curiae, o que lhes confere maior segurança e legitimidade. Por essas razões sua aplicação não enseja maiores complicações pragmáticas.

\footnotetext{
${ }^{9}$ Para melhor compreender a competência dos tribunais para edição de precedentes ver MARINONI (2017). Para compreender os conceitos essenciais da estrutura dos precedentes judiciais e distinção entre os provimentos judiciais vinculativos ver MITIDIERO (2017).

${ }^{10}$ Adota-se aqui o conceito coexistencial de acesso à justiça proposto pelo Cappelletti e Garth (1999).

${ }^{11}$ Os precedentes judiciais formados a partir dos julgamentos da ADPF n ${ }^{\circ} 186$, do ADO no 26 e MI nº 4733, no âmbito do Supremo Tribunal Federal, são emblemáticos neste sentido.
} 


\subsection{Julgamento liminar com fundamento em teses jurídicas fixadas em incidentes de resolução de demandas repetitivas e em assunção de competência}

O julgamento com fundamento no art. 332, III, do CPC está alinhado, do ponto de vista hermenêutico, com o padrão decisório estabelecido pelo art. 926 do código. É evidente a necessidade de se estabilizar e harmonizar a jurisprudência nas demandas seriais, sobretudo para evitar violações aos princípios da isonomia e da segurança jurídica.

A extensão da tese jurídica fixada no julgamento do incidente de demandas repetitivas depende do tribunal competente para apreciá-lo (art. 976). Se o incidente for julgado por um determinado tribunal de justiça, a eficácia vinculante se restringirá aos limites da competência do respectivo tribunal. Não obstante, se houver interposição de recursos excepcionais contra a tese fixada pelo tribunal local, a extensão da tese jurídica alcançará todo território nacional, como ocorre nos incidentes julgados pelo Superior Tribunal de Justiça ou pelo Supremo Tribunal Federal.

Com efeito, admitir processamento de determinada demanda contrária a tese jurídica corresponde à negação da integridade (DWORKIN, 2010) do direito proposta no art. 926 do CPC. Considerando essa premissa, o julgamento liminar com fundamento no art. 332, III, constitui importante instrumento de estabilização vertical dos provimentos judiciais proferidos pelos tribunais.

O mesmo raciocínio se aplica às decisões proferidas no julgamento de incidente de assunção de competência (art.947). O objetivo do incidente é a formação de jurisprudência uniformizadora, no âmbito dos tribunais, sempre que a causa envolver relevante questão de direito ou grande repercussão social. O principal fundamento jurídico para a instauração do incidente não é multiplicidade de processo idênticos, ao contrário do que ocorre no incidente de resolução de demandas repetitivas. O fundamento é, portanto, qualitativo e tem como propósito prevenir controvérsias sobre temas relevantes através da denominada jurisprudência uniformizadora (MITIDIERO, 2017).

Rejeitar, liminarmente, pedidos que contrarie decisão proferida em julgamento de assunção de competência constitui técnica processual adequada para evitar divergência jurisprudencial descabida acerca de temas jurídicos relevantes. A improcedência liminar do pedido, nessas hipóteses, é imperiosa.

\subsection{Julgamento liminar com fundamento em súmulas dos tribunais de justiça sobre direito local}


Permitir o julgamento liminar com objetivo de preservar as súmulas dos tribunais sobre direito local é medida necessária para se manter a estabilidade da jurisprudência no âmbito regional. A atuação judicante dos tribunais é essencial para se manter a segurança jurídica e isonomia no julgamento de controvérsias sobre direito local, especialmente, num país continental como o Brasil, onde os estados possuem intensa atividade legislativa.

Nesta toada, as súmulas sobre direito local constitui importante orientação sobre aplicação do direito local. Com efeito, admitir pedidos contrários às súmulas sobre direito local contribui para fragilizar a uniformização da jurisprudência no contexto dos Estados federados.

Há, todavia, duas advertências a se fazer. A improcedência liminar do pedido com fundamento em súmula de tribunal local não pode prescindir do prévio distinguishing. Tal advertência tem como justificativa os mesmos argumentos dispendidos na análise da improcedência liminar com base em súmulas do STF e do STJ.

A segunda advertência diz respeito à contradição entre as súmulas de determinado tribunal local com as súmulas dos tribunais superiores. Neste caso não será cabível a aplicação do art. 332, IV, do CPC. O argumento é simples. O código pressupõe uniformização vertical dos precedentes judiciais editados pelos tribunais superiores. Tal proposta normativa exige sincronia entre as súmulas dos tribunais locais e as editadas pelos tribunais superiores.

\subsection{Julgamento liminar com fundamento no reconhecimento da prescrição e decadência}

A improcedência liminar do pedido nos casos de reconhecimento de prescrição e decadência não foi criada pelo Código de Processo Civil de 2015. O código revogado já dispunha sobre a possibilidade de indeferimento da petição inicial (art. 295, IV) nas hipóteses de prescrição e decadência. A mesma crítica, que foi elaborada por parcela da doutrina ao dispositivo mencionado acima, se aplica ao art. $332, \S 1^{\circ}$ do código vigente.

O reconhecimento da prescrição e decadência necessita da análise acurada das circunstâncias de fato para aferição correta sobre sua ocorrência ou não ${ }^{12}$. Por essa razão que não há como se reconhecer a prescrição ou decadência sem o exercício de um contraditório prévio. Este entendimento se coaduna coma regra do art. 10 do Código de Processo Civil. Mesmo nos casos de matéria de ordem pública, como prescrição e decadência, o juiz deverá ouvir as partes antes de decidir.

\footnotetext{
${ }^{12}$ Diante da importância do tema o Superior Tribunal de Justiça editou em 17/06/2019 03 novas súmulas (633,634 e 635) sobre prescrição e decadência no direito administrativo, objetivando minimizar dúvidas no âmbito da administração pública.
} 
Não há como reconhecer a prescrição ou decadência sem permitir ao autor da demanda, antes de se proferir sentença, se manifestar de forma consistente sobre a ocorrência ou não da causa extintiva de seu direito. A interpretação sistemática do código sugere esta compreensão ${ }^{13}$.

Por outro lado, é preciso destacar que há, da mesma forma, óbices normativos, conforme bem aponta a literatura processual. Fredie Didier (2015, p. 604) destaca que há incompatibilidades entre o art. 332, $\S 1^{\circ}$, do Código de Processo Civil e o art. 191 do Código Civil, que admite a renúncia, expressa ou tácita, da prescrição pela parte interessada. A partir desta linha de reflexão o autor sugere que o reconhecimento de ofício da prescrição somente será cabível nas demandas que trate de direitos indisponíveis, sendo inadmissível quando se tratar de direitos disponíveis ou nos casos em que desfavoreça os sujeitos protegidos constitucionalmente (consumidor, índio, idoso e trabalhador). Essas peculiaridades concernentes ao reconhecimento da prescrição e da decadência dificultam sua apreciação em julgamento liminar.

\section{JULGAMENTO LIMINAR E A PODENDERAÇÃO DE PRINCÍPIOS: APLICABILIDADE E CONTROLE}

Barbosa Moreira (2004), em texto clássico, destacou que um dos principais mitos da justiça é a celeridade. No entanto, a busca pela celeridade, enquanto ideal, não pode ofuscar ou mesmo anular o resultado útil do processo, sobretudo diante do modelo de processo proposto pelo $\mathrm{CPC} / 2015$, que visa a solução integral do mérito (art.4 $4^{\circ}$ ).

Não há dúvidas no sentido de que o julgamento liminar contribuirá para a prestação efetiva da tutela jurisdicional. Em outra perspectiva, o julgamento liminar favorece a administração da justiça em, pelo menos, duas linhas de atuação, que são distintas mas que se complementam. A primeira concerne ao julgamento célere e isonômico das demandas repetitivas. O volume de ações repetitivas em áreas específicas como direito do consumidor, direito previdenciário ou mesmo direito tributário, exige tratamento célere e isonômico, reduzindo a insegurança jurídica que é inerente às demandas de massa.

A segunda linha de atuação relaciona-se com o fortalecimento de precedentes judiciais proposto pelo novo modelo de processo. $\mathrm{O}$ art. 332 deve ser interpretado em conjunto com o art. 927 do código. O fortalecimento da dinâmica dos precedentes judiciais no processo civil brasileiro passa, necessariamente, pela interpretação teleológica e sistemática de diversos dispositivos legais. Sem este exercício hermenêutico não há como se pensar num sistema de

\footnotetext{
${ }^{13}$ A aplicação da Súmula 229 do Superior Tribunal de Justiça enseja algumas divergências. O verbete possui a seguinte redação: O pedido do pagamento de indenização à seguradora suspende o prazo de prescrição até que o segurado tenha ciência da decisão. O terma ciência da decisão, em alguns casos, pode exigir análise pormenorizada em cada caso de modo a evitar aplicação indevida sobre o reconhecimento da prescrição. A decisão proferida na Apelação n ${ }^{\circ}$ 0287733-56.2016.8.19.0001, julgada pelo Tribunal de Justiça do Estado do Rio de Janeiro representa uma evidência importante neste sentido.
} 
precedentes judiciais no sentido concebido pela exposição de motivos do código, redigida pela comissão de juristas que elaborou o anteprojeto.

Numa outra dimensão, não se pode analisar o julgamento liminar somente pela perspectiva da administração da justiça. Se faz premente compreender o julgamento liminar sob a ótica do acesso à justiça, em sentido substancial ${ }^{14}$, e da efetividade do processo. A finalidade primária da tutela jurisdicional é produzir resultados práticos na vida dos jurisdicionados. Para tanto há que se conciliar celeridade com a adequada prestação da tutela jurisdicional.

Nesta linha de análise é essencial extrair do art.332 do CPC uma interpretação que esteja alinhada com o direito constitucional processual e seus princípios. Porquanto, visa-se, nesta etapa do trabalho, apresentar algumas propostas hermenêuticas a partir de uma perspectiva holística do Código de Processo Civil de modo a se alcançar a adequada aplicabilidade das regras referentes ao julgamento liminar, como também estabelecer limites e as formas de controle de eventuais arbitrariedades.

\subsection{Da necessidade do contraditório prévio e da aplicação do princípio da cooperação nos casos de incidência do julgamento liminar}

O julgamento liminar, nos termos do art. 332 , dispensa o contraditório prévio ${ }^{15}$. A dispensa é compreensível na medida em que decisão será proferida em favor do réu, que obterá êxito na demanda sem ter a necessidade de apresentar defesa, em princípio ${ }^{16}$. Todavia, há que se aplicar aqui o conceito amplo de contraditório.

Contraditório, em sentido lato, não se limita à contraposição de argumentos ou manifestação sobre requerimentos da parte contrária. Possui um significado mais profundo que se caracteriza pela possibilidade das partes influenciar na formação da decisão judicial a ser proferida. Partindo desta premissa, há hipóteses em que o contraditório prévio ${ }^{17}$ é fundamental para dar maior segurança jurídica na utilização da técnica de julgamento liminar.

\footnotetext{
${ }^{14}$ Acesso à justiça, numa perspectiva substancial, significa não só acesso ao Poder Judiciário mas, essencialmente, assegurar a efetiva análise da pretensão do autor deduzida em juízo num tempo razoável. A solução integral do mérito, enquanto norma fundamental insculpida no art. $4^{\circ}$ do CPC, retrata essa proposta conceitual. Não basta acessar o Poder Judiciário, enquanto instituição, mas se faz primordial sair em tempo hábil e com sua pretensão devidamente apreciada pelo Judiciário. Importante ressaltar que Kazuo Watanabe, processualista paulista, foi o principal articulador desta perspectiva de análise na literatura processual brasileira.

${ }^{15} \mathrm{O}$ art. 332, $\S 2^{\circ}$ admite a interposição de recurso de apelação contra sentença liminar proferida. Entretanto, a possibilidade de recorrer não constitui exercício do contraditório, pois não oportunizou à parte prejudicada influir na formação da decisão.

${ }^{16}$ Fredie Didier Jr (2015, p. 593) é categórico ao afirmar que a improcedência liminar se constitui como uma técnica de aceleração do processo e é cabível nas situações de manifesta improcedência do pedido. Segundo Didier não há necessidade de ouvir o demandado pois este sairá vitorioso.

${ }^{17}$ Para Luiz Guilherme Marinoni, Sérgio Cruz Arenhart e Daniel Mitidiero o autor poderá se manifestar, para fazer o distinguishing, por meio de recurso de apelação, o que permitirá ao juiz exercer o juízo de retratação. Neste caso o contraditório será posterior à improcedência liminar, o que impedirá o próprio exercício da cooperação antes da formação da decisão de mérito (2015, p. 169).
} 
A improcedência liminar do pedido com fundamento no art. 332, I, exige cuidados do julgador em razão da limitação argumentativa das súmulas. Não há possibilidade de um verbete contemplar a extensão dos fatos debatidos em uma demanda. Há também os riscos de superação ou mesmo limitação do verbete. De outro modo, não são raros os casos em que as súmulas são utilizadas de forma equivocada por tratar de questão de fundo diversa do caso sub judice.

Por essas razões, a improcedência liminar, com fundamento em súmulas do Supremo Tribunal Federal ou do Superior Tribunal de Justiça, deve ser operada com a participação, no mínimo, da parte autora. A medida é salutar, pois o cotejo analítico ou mesmo o distinguishing será feito pelo juiz e com a participação da parte que será afetada diretamente por eventual improcedência liminar.

É evidente que se faz necessário analisar em profundidade, empiricamente, qual o impacto da técnica de julgamento liminar no contexto dos tribunais brasileiros, mas há evidências no sentido de que o contraditório prévio contribui para o aprimoramento da atividade judicante neste particular. O Tribunal de Justiça do Estado do Rio de Janeiro ${ }^{18}$, em acórdão interessante, reformou decisão que aplicou de forma indevida a improcedência liminar.

Isto porque, apesar de a jurisprudência do STJ, no verbete de súmula $\mathrm{n}^{\circ} 382$, ter sedimentado que "a estipulação de juros remuneratórios superiores a $12 \%$ ao ano, por si só, não indica abusividade", por ocasião da análise do Recurso Repetitivo n. 1.112.879/PR, em acórdão da lavra da Min. NANCY ANDRIGHI, firmou-se a tese, na Corte Superior, de que "o juiz deve limitar os juros à média de mercado nas operações da espécie, divulgada pelo Bacen, salvo se a taxa cobrada for mais vantajosa para o cliente".

Como se nota, o caso concreto não comporta o julgamento liminar de improcedência, disciplinado pelo art. 332 do CPC/2015, uma vez que o pedido inicial não contraria entendimento pacífico dos Tribunais e a ação necessita de instrução processual, considerando que o ponto nodal da questão não é o fato de a taxa de juros estar ou não expressa no contrato, mas sim o seu percentual em relação à média de mercado.

O julgado acima destacado demonstra a necessidade de se realizar o distinguishing nos casos em que se aplicará a regra do art. 332, I, do CPC. Um verbete de súmula, por si só, não permite o adequado julgamento da causa. É imprescindível ponderar sobre os julgados que ensejaram a edição da súmula. O contraditório prévio permitirá, a um só tempo, o aprimoramento do método de julgamento com base em precedentes judiciais como também evitará o excesso de trabalho, desnecessário, dos respectivos tribunais na revisão de julgamentos liminares eivados de nulidade ${ }^{19}$. A mesma linha de análise se estende ao julgamento liminar com fulcro em acórdãos do Supremo Tribunal Federal (art. 332, II).

\footnotetext{
${ }_{18}$ Apelação Cível no 0079802-15.2018.8.19.0001, Décima Sétima Câmara Cível, Relator Des. Marcia Ferreira Alvarenga, Julgado em 06/02/2019. Acesso em 17 junho 2019.

${ }^{19}$ Proposta similar foi apresentada por Humberto Theodoro Junior, Dierle Nunes, Alexandre Bahia e Flávio Quinaud (2015, p. 363). Os autores defendem, em poucas linhas, a necessidade de abertura de prazo para manifestar do autor de modo lhe permitir realizar o distinguishing.
} 
Numa outra dimensão, o princípio da colaboração é o vetor estruturante e axiológico da relação processual estabelecida entre as partes e o juiz, conforme dispõe o art. $6^{\circ}$ do CPC. A importância deste princípio como estruturante da relação jurídica processual se evidência em diversas regras do código. A mais importante diz respeito à vedação às decisões surpresas, nos termos dos arts. $9^{\circ}$ e 10.

A assertiva através da qual se impede o julgador de proferir decisões sem a prévia oitiva das partes, mesmo nos casos que envolva matéria de ordem pública, expressa de forma nítida, o modelo dialógico proposto pelo novo ordenamento processual. O princípio da cooperação também informa a técnica de julgamento liminar, principalmente nos casos que envolver reconhecimento de prescrição e decadência.

Os fenômenos da prescrição e decadência perpassam tanto as relações jurídicas de direito privado como as de direito público, ao passo que representam importante parcela dos recursos julgados pelos tribunais de justiça, principalmente no âmbito do direito tributário. $\mathrm{O}$ reconhecimento judicial desta causa extintiva do direito do demandante, em muitos casos, requer análise pormenorizada dos fatos, pois mesmo um pequeno equívoco pode fulminar o direito deduzido em juízo. Este é entendimento é majoritário na literatura processual (DIDIER, 2015; MEDINA, 2015; THEODORO JUNIOR, NUNES, BAHIA e PERDRON, 2015.

\subsection{Da aplicação dos princípios da duração razoável do processo e da primazia do mérito}

Os princípios da duração razoável do processo e da primazia da decisão de mérito estão dispostos no art. $4^{\circ}$ do Código de Processo Civil. Embora o princípio da duração razoável do processo esteja previsto no texto constitucional (art.5 $5^{\circ}$ LXXVIII), o código reproduziu o referido princípio com o intento de não deixar dúvidas acerca da constitucionalização do processo e da sua irradiação para todos os atos processuais.

Por sua vez, o princípio da primazia do mérito ${ }^{20}$ dialoga com o princípio da duração razoável do processo na medida em que é essencial alinhar celeridade com apreciação justa e adequada do mérito da causa. Nesta linha de análise, a técnica de julgamento liminar contribuirá de forma decisiva para o aprimoramento da tutela jurisdicional no âmbito das demandas seriais, se aplicada da forma proposta neste trabalho, observando, em questões cruciais como foi apontado acima, o contraditório prévio e o modelo cooperativo de processo.

Kazuo Watanabe (2012) ratifica que a cognição, seja ela sumária ou exauriente, não pode descurar dos corolários do conceito de devido processo legal tais como o contraditório, economia processual, publicidade dos atos, entre outros. E é no procedimento que o Estado consegue articular estes princípios de modo a obter tutela jurisdicional que atenda, ao mesmo

${ }^{20}$ Expressão utilizada por Fredie Didier (2015). 
tempo, às exigências da pretensão deduzida em juízo, à urgência da tutela, à definição da solução de mérito, entre outros aspectos, além das opções técnicas e políticas do legislador.

É possível, com este aporte teórico, conciliar técnicas de aceleração do processo, como a improcedência liminar, sem negligenciar as normas fundamentais do direito processual civil. Contribuir para esta reflexão é a intenção primeira deste trabalho.

\subsection{Por uma teoria conglobante da decisão judicial}

O exercício reflexivo levado a efeito nas linhas acima sugerem a necessidade de se aprimorar a teoria da decisão judicial no processo civil brasileiro. O Código de Processo Civil de 2015 inovou ao fortalecer, do ponto de vista normativo, diversas técnicas de aceleração do processo. Contudo, essas inovações demandam uma nova concepção teórica abrangente que articule a participação democrática dos sujeitos processuais, o devido processo legal e o modelo cooperativo de processo mediados pelas normas fundamentais do processo civil.

Técnicas processuais como tutela provisória antecedente (art. 303) e sua estabilização, improcedência liminar (art. 332) e julgamento parcial do mérito (art. 356), apenas para exemplificar, são importantes para assegurar o julgamento da causa num tempo razoável, mas exigem, portanto, uma reconstrução da teoria da decisão que foi estruturada no período de vigência do código revogado.

Rafael Lazzarotto (2017) é categórico ao afirmar que as diversas teorias da decisão que foram elaboradas ao longo dos anos tiveram em comum a preocupação com a segurança e a legitimidade. Para este autor as teorias pragmatista, hermenêuticas, sistêmicas, substancialistas, pragmatista, entre outras, a despeito de suas singularidades foram concebidas para superar as dificuldades decorrentes da insegurança ou mesmo para dar maior legitimidade à decisão judicial proferida. Entretanto, essas teorias foram concebidas, em maior ou menor grau, inserindo o juiz como epicentro na construção da decisão judicial.

O Código de Processo Civil, neste contexto, provocou uma verdade crise de paradigmas, no sentido proposto por Kuhn (2017), no campo da teoria da decisão judicial. É preciso reconstruí-la a partir de um novo escopo. Uma teoria da decisão judicial que contemple dimensões democratizantes do processo decisório (CATHARINA, 2015) é fundamental para que técnicas de aceleração do processo, como a improcedência liminar, assegurem a duração razoável do processo sem descuidar do amplo acesso à justiça. A teoria procedimentalista discursiva de Habermas (2003), neste contexto, contribui, de forma efetiva, para articular as técnicas de aceleração do processo e com o modelo dialógico, democrático e cooperativo proposto pelo código.

Não se concebe, no processo civil brasileiro, decisão judicial proferida de forma solipsista, ainda que fundamentada numa técnica de aceleração do processo como a improcedência liminar do pedido. Partindo desta mesma premissa teórica, Eder Fernandes 
(2016) destaca as potencialidades da teoria habermasiana no contexto processual brasileiro. O princípio do discurso de Habermas (2003) ganha facticidade no campo do contraditório prévio no julgamento liminar nas hipóteses do art. 332, incisos I, II e $§ 1^{\circ}$ do CPC.

Não há como se pensar um processo civil democrático sem uma teoria da decisão judicial que tem como eixo a democratização do processo decisório, independente da técnica de julgamento aplicada. Com efeito, a teoria do direito de Habermas contribui para se estudar a teoria da decisão judicial na vigência do CPC/2015.

\section{CONCLUSÃO}

A improcedência liminar do pedido constitui técnica essencial para se alcançar a proposta de um processo com uma duração razoável. Com efeito, conforme se demonstrou ao longo do trabalho, o tratamento normativo dado ao tema pelo código não é exaustivo, o que pode acarretar violações complexas ao princípio do acesso à ordem jurídica justa.

Para evitar arbitrariedades ou mesmo desuso, se faz imperioso interpretar o art. 332 do CPC à luz das normas fundamentais do processo civil de modo a extrair o máximo de seu conteúdo normativo. Foi exatamente nesta perspectiva que propomos interpretar o referido dispositivo legal sob a ótica dos princípios estruturantes do processo civil como fonte supletiva.

Admitir o contraditório prévio, de forma cooperativa, e observando a primazia do mérito nos casos dispostos no art. 332, I, II e $\$ 1^{\circ}$, significa, essencialmente, dar maior eficácia e concretude à técnica de julgamento liminar. Essa proposta hermenêutica exige maior preparação e cautela dos operadores do direito.

As técnicas de aceleração do processo dispostas no Código de Processo Civil clamam por uma reconstrução da teoria da decisão judicial de modo a articular estas técnicas como o modelo cooperativo e democrático de processo, que ganha facticidade no exercício pleno contraditório prévio. Esse é o viés conceitual e teórico por meio do qual pode-se extrair todas as potencialidades do julgamento liminar enquanto técnica constitucional de aceleração do processo.

O presente trabalho tem como pretensão maior estimular, ainda mais, o debate sobre a temática como também deslocar a reflexão para o campo da reconstrução da teoria da decisão judicial e da democratização do processo, pois são essas as categorias essenciais para se pensar o modelo de processo que está se consolidando no Brasil. 


\section{REFERÊNCIAS}

BARBOSA MOREIRA, José Carlos. O Futuro da Justiça: alguns mitos. In: Temas de direito processual, oitava série. São Paulo: Saraiva, 2004. p. 01-14.

BRASIL. Conselho Nacional de Justiça. Justiça em números 2018. Disponível em: http://www.cnj.jus.br/files/conteudo/arquivo/2018/09/8d9faee7812d35a58cee3d92d2df2f25.p df, acesso em 20 junho 2019.

BRASIL. Lei $\mathrm{n}^{\circ} 13.105$, de 16 de março de 2015. Código de Processo Civil. Brasília, DF: Presidência da República, [2015]. Disponível em: <http://www.planalto.gov.br/ccivil_03/_ato2015-2018/lei/I13105.htm> Acesso em: 20 junho 2019.

BRASIL. Tribunal de Justiça do Estado do Rio de Janeiro. Acórdão de decisão que reformou a improcedência liminar. Apelação Cível nº 0079802-15.2018.8.19.0001. Marcus Walerius Falcoeiras Trindade e Crefisa S/A Crédito, Financiamento e Investimentos. Relator: Desembargadora Marcia Ferreira Alvarenga. 06 de fevereiro 2019. Disponível em: http://www4.tjrj.jus.br/ejud/ConsultaProcesso.aspx? $\mathrm{N}=201900100322$. Acesso em: 17 junho 2019.

CAPPELLETTI, Mauro. GARTH, Bryant. Acesso à justiça. Trad. Ellen Gracie Northflleet. Porto Alegre: Sérgio Antônio Fabris, 1999.

CATHARINA, Alexandre de Castro, Movimentos sociais e a construção dos precedentes judiciais. Curitiba: Juruá, 2015.

DIDIER, Fredie. Curso de Direito Processual Civil. 17 ed. Podivm: Salvador, 2015.

DWORKIN, Ronald. Levando os direitos a sério. 3. ed. São Paulo: Martins Fontes, 2010.

FERNANDES, Eder. Entre direitos fundamentais e democracia: superando a dicotomia no direito brasileiro. Niterói: Eduff, 2016.

HABERMAS, Jurguen. Direito e democracia: entre facticidade e validade. 2. ed. Rio de Janeiro: Tempo Brasileiro, 2003. 2 v.

KUHN, Thomas. A estrutura das revoluções científicas. São Paulo: Perspectiva, 2017.

LOPES FILHO, Juraci Mourão. Os precedentes judiciais no constitucionalismo brasileiro contemporâneo. Salvador: Juspodivm, 2014.

MARINONI, Luiz Guilherme. Julgamento nas cortes supremas: precedentes e decisão do recurso diante do novo CPC. 2. ed. São Paulo: Revistas dos Tribunais, 2017.

MARINONI, Luiz Guilherme; ARENHART, Sérgio Cruz; MITIDIERO, Daniel. Curso de Processo Civil: Tutela dos direitos mediante procedimento comum. São Paulo: Revista dos Tribunais, 2015. 
MEDINA, José Miguel Garcia. Direito processual civil moderno. São Paulo: Revista dos Tribunais, 2015.

MITIDIERO, Daniel. Precedentes judiciais: da persuasão à vinculação. São Paulo: Revista dos Tribunais, 2017.

NUNES, Dierle José Coelho. Processo jurisdicional democrático: uma análise crítica das reformas processuais. Curitiba: Juruá, 2012.

SIMONI, Rafael Lazzarotto. Decisão, organização e risco: a forma de decisão jurídica para além da segurança e da legitimidade. Revista Nomos. V. 37.1, jan./jun. 2017.

TARUFFO, Michele. Precedente e jurisprudência. Trad. Chiara de Teffé. Civilistica.com. Rio de Janeiro, a. 3, n. 2, jul.-dez./2014.

THEODORO JUNIOR, Humberto. NUNES, Dierle. BAHIA, Alexandre Melo Franco. PEDRON, Flavio Quinaud. Novo CPC - Fundamentos e sistematização. Rio de Janeiro: Forense, 2015.

WATANABE, Kazuo. Cognição no processo civil. São Paulo: Saraiva, 2012. 